\title{
Electrospray Ionization/Tandem Quadrupole Mass Spectrometric Studies on Phosphatidylcholines: The Fragmentation Processes
}

\author{
Fong-Fu Hsu and John Turk \\ Mass Spectrometry Resource, Division of Endocrinology, Diabetes, and Metabolism, Department of Internal \\ Medicine, Washington University School of Medicine, St. Louis, Missouri, USA
}

\begin{abstract}
We applied low-energy collisionally activated dissociation (CAD) tandem quadrupole mass spectrometry to study the fragmentation pathways of the $[\mathrm{M}+\mathrm{H}]^{+}$and $[\mathrm{M}+\mathrm{Li}]^{+}$ions of phosphatidylcholine (PC), generated by electrospray ionization (ESI). It is revealed that the fragmentation pathways leading to loss of the polar head group and of the fatty acid substituents do not involve the hydrogens attached to the glycerol backbone as previously reported. The pathway for formation of the major ion of $m / z 184$ by loss of the polar head group from the $[\mathrm{M}+\mathrm{H}]^{+}$precursor of a diacyl PC involves the participation of the $\alpha$-hydrogen of the fatty acyl substituents, whereas the $\mathrm{H}^{+}$participates in the loss of fatty acid moieties. The $\alpha$-hydrogens of the fatty acid substituents also participate in the major fragmentation processes, including formation of $\left[\mathrm{M}+\mathrm{Li}-\mathrm{R}_{x} \mathrm{CO}_{2} \mathrm{H}\right]^{+}$and $\left[\mathrm{M}+\mathrm{Li}-59-\mathrm{R}_{x} \mathrm{CO}_{2} \mathrm{H}\right]^{+}$ions for the $[\mathrm{M}+\mathrm{Li}]^{+}$ions of diacyl PCs, when subjected to low-energy CAD. These fragmentation processes are deterred by substitution of the fatty acyl moieties with alkyl, alkenyl, or hydroxyl groups and consequentially, result in a distinct product-ion spectrum for various PC, including diacyl-, plasmanyl- plasmenyl-, and lyso-PC isomers. The $\alpha$-hydrogens of the fatty acyl substituents at $s n-2$ are more labile than those at $s n-1$. This is reflected by the preferential loss of the $\mathrm{R}_{1} \mathrm{CO}_{2} \mathrm{H}$ over the $\mathrm{R}_{2} \mathrm{CO}_{2} \mathrm{H}$ observed for the $[\mathrm{M}+\mathrm{Li}]^{+}$ions of diacyl PCs. The spectrum features resulting from the preferential losses permit identification and assignment of the fatty acid moieties in the glycerol backbone. The new fragmentation pathways established by tandem and source CAD tandem mass spectra of various PC molecules, including deuteriumlabeling analogs, were proposed. These pathways would clarify the mechanisms underlying the ion formations that lead to the structural characterization of PC molecules. (J Am Soc Mass Spectrom 2003, 14, 352-363) @ 2003 American Society for Mass Spectrometry
\end{abstract}

$\mathrm{P}^{\prime}$ hospholipids are essential components of cellular membranes, and distinct molecular species are differentially distributed among tissue and within subcellular compartment [1-4]. Among the phospholipids found in mammalian cell membranes, phosphatidylcholine species are the most abundant constituents. Diversity of choline glycerophospholipid, similar to other glycerophospholipid classes, lies mainly in the subclass defined by the chemical modality at $s n-1$, as designated 1,2-diacyl-, 1-O-alk-1'-enyl-2-acyl(plasmalogen), and 1-O-alkyl-2-acyl-phosphocholine (plasmanylcholine), as well as in the size and unsaturation sites in the radyl groups in the subclass.

PC contains a quaternary nitrogen with a fixed positive charge and more readily form positive than

Published online March 14, 2003

Address reprint requests to Dr. F.-F. Hsu, Department of Internal Medicine, Washington University School of Medicine, 600 S. Euclid, Box 8127, St. Louis, MO 63110, USA. E-mail: fhsu@im.wustl.edu negative ions by electrospray ionization (ESI). The tandem mass spectra produced by CAD of PC in the positive-ion mode as a protonated or an alkali adduct ion are similar when ionization is achieved by FAB or ESI. The product-ion spectra of the protonated adducts of PC are dominated by a phosphocholine ion and ions that identify the fatty acid substituents are of low abundance $[5,6]$. In contrast, the product-ion spectra generated by CAD of the alkali metal adduct ions yield abundant fragment ions that permit assignment of the identities and positions of fatty acid substituents [6-8].

Several articles [6-9] and reviews [5, 10] discussed the mechanisms that underlie the fragmentation of PC under low-energy and high-energy CAD. The proposed pathway for cleavage of the phosphocholine head group for the protonated molecular PC (Scheme 1a) was thought to involve the participation of the hydrogens at the glycerol backbone [5-10]. The hydrogens were also thought to participate in the fragmentation processes leading to losses of fatty acid moieties, and loss of 


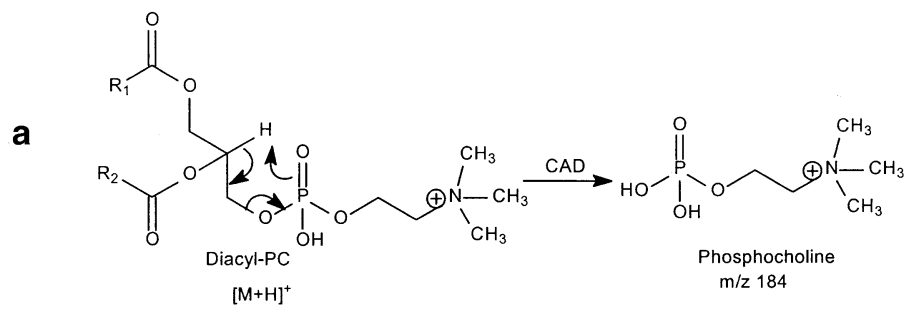

The fragmentation pathway proposed by Murphy et.al. [5] for formation of the $\mathrm{m} / \mathrm{z} 184$ ion from [M+H] $]^{+}$ion of $\mathrm{PC}$

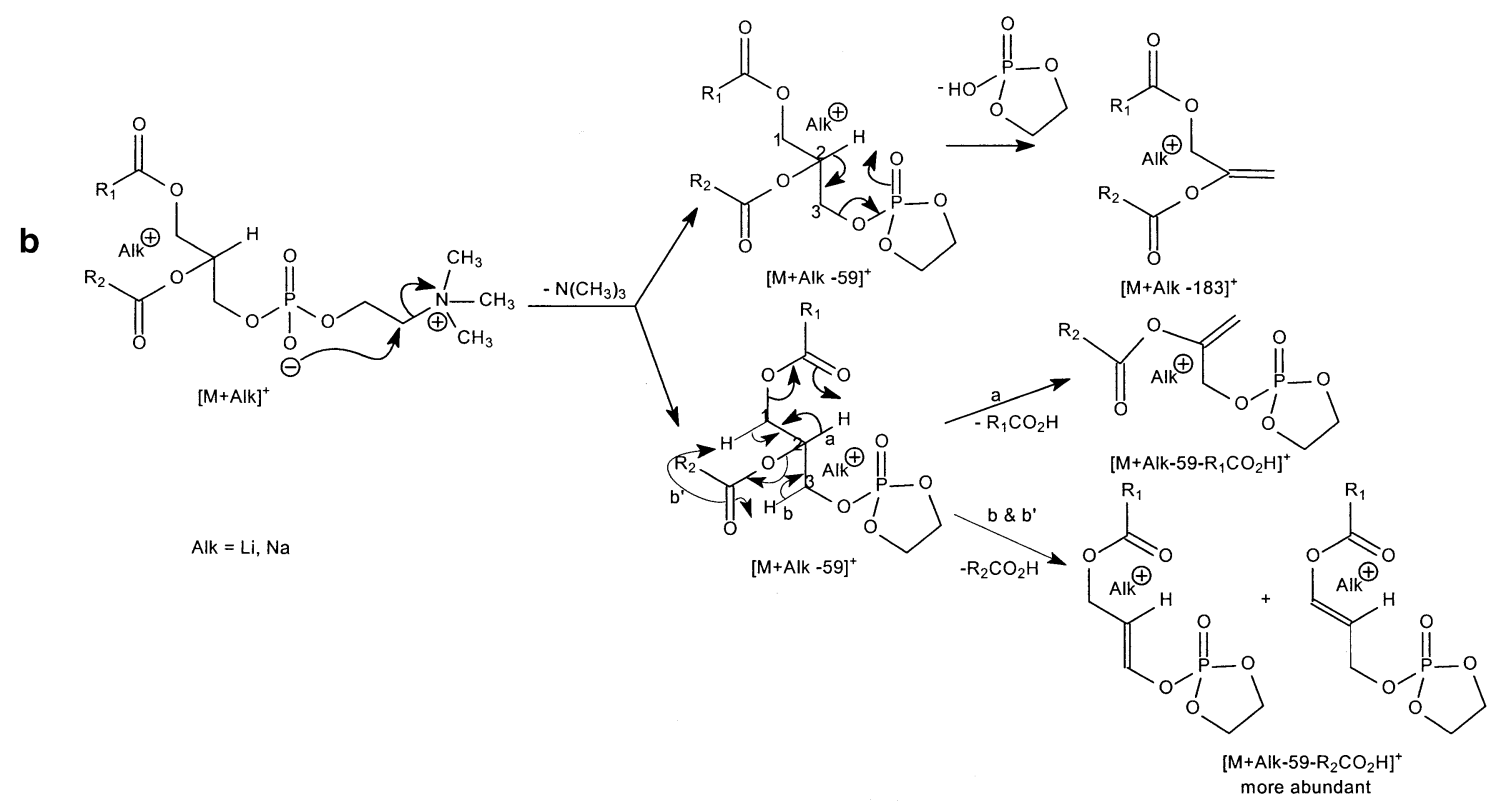

The fragmentation pathways for formation of the $[\mathrm{M}+\mathrm{Alk}-183]^{+}$and $\left[\mathrm{M}+\mathrm{Alk}-59-\mathrm{R}_{\mathrm{x}} \mathrm{CO}_{2} \mathrm{H}\right]^{+}$ions previously proposed for alkali metal adduct ions of $\mathrm{PC}[5-9]$

Scheme 1

O,O'-dimethylenephosphoric acid following an initial expulsion of trimethylamine for the alkali metal adduct ions (Scheme 1b) [5-9]. However, our studies with deuterium labeling PC analogs indicate that the fragmentation processes involve the participation of the $\alpha$-hydrogens of the fatty acid substituents or the available exchangeable protons residing in the molecules, rather than the hydrogens as previous suggested. We proposed new pathways leading to fragmentations for PC under low-energy CAD, based on the findings resulting from various product-ion mass spectra, obtained with quadrupole tandem and source-CAD tandem mass spectrometry. These new fragmentation pathways would clarify the mechanisms underlying the ion formations that lead to the structural identification of various subclasses of PC molecules.

\section{Experimental}

\section{Chemicals}

Standard PC species with defined fatty acid substituents were obtained either from Avanti Polar Lipids (Alabaster, AL) or Sigma (St. Louis, MO). Solvents and lithium hydroxide were purchased from Fisher Chem- ical (Pittsburgh, PA). The diacyl-, 1-O-alkyl-2-acyl(plasmanyl-), and 1-O-alk-1'-enyl-2-acyl (plasmalogen) phosphocholines, e.g., the dipalmitoyl-, 1-O-hexadecyl2-palmitoyl-, and 1-O-hexadec-1'-enyl-2-palmitoyl-snglycero-3-phosphocholines were designated as 16:0/16: 0-PC, a16:0/16:0-PC, and p16:0/16:0-PC, respectively. For lysophosphocholine standards, for examples, 1-palmitoyl-2-hydroxy-, 1-hydroxy-2-palmitoyl-, 1-O-hexadecyl2-hydroxy-, and 1-O-hexadec-1'-enyl phosphocholines, were designated as 16:0/lyso2-PC, lyso1/16:0-PC, a16: 0/lyso2-PC, and $p 16: 0 /$ lyso2-PC, respectively.

\section{Mass Spectrometry}

Low-energy ESI CAD tandem mass spectrometry experiments were conducted on a Finnigan (San Jose, CA) TSQ 7000 mass spectrometer equipped with ICIS data system. Each solution (methanol/chloroform 4/1), containing $10 \mathrm{pmol} / \mu \mathrm{L}$ was continuously infused into the ESI source with a Harvard syringe pump at a flow rate of $1 \mu \mathrm{L} / \mathrm{min}$. All the choline glycerophospholipids yield intense alkali metal adduct ion in the presence of $\mathrm{Li}^{+}, \mathrm{Na}^{+}$, or $\mathrm{K}^{+}$. The skimmer was at ground potential and the electrospray needle was set at $4.5 \mathrm{kV}$. The 

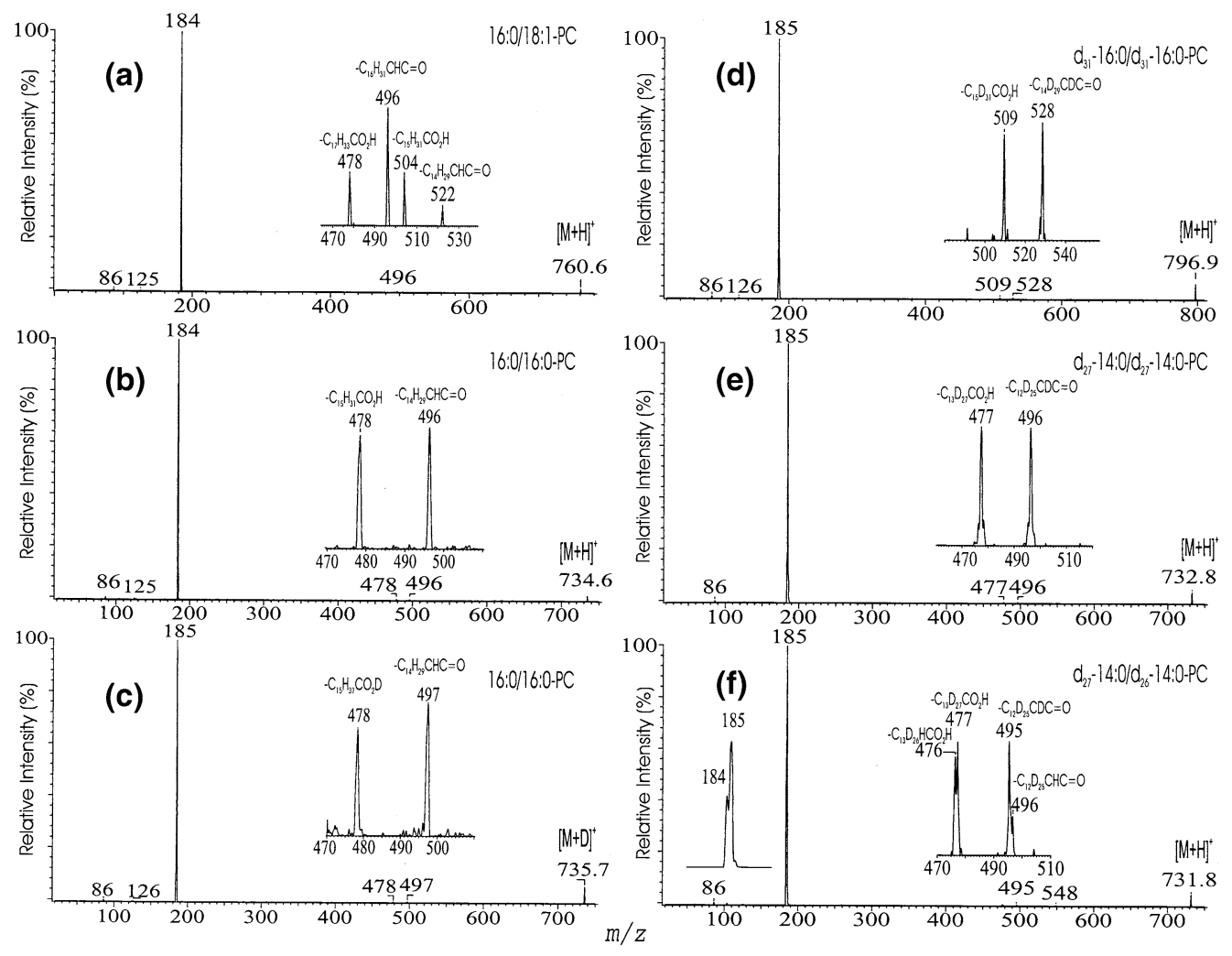

Figure 1. The product-ion spectra of the $[\mathrm{M}+\mathrm{H}]^{+}$ions of (a) 16:0/18:1-PC $(\mathrm{m} / \mathrm{z}$ 760.6), (b) 16:0/16:0-PC (m/z 734.6), (d) $\mathrm{d}_{31}-16: 0 / \mathrm{d}_{31}-16: 0-\mathrm{PC}(\mathrm{m} / \mathrm{z} 796.9),(\mathbf{e}) \mathrm{d}_{27}-14: 0 / \mathrm{d}_{27}-14: 0-\mathrm{PC}(\mathrm{m} / \mathrm{z} 732.8)$, and (f) $\mathrm{d}_{27}-14: 0 / \mathrm{d}_{26}-14: 0-\mathrm{PC}(\mathrm{m} / \mathrm{z} 731.8)$. The product-ion spectrum of the $[\mathrm{M}+\mathrm{D}]^{+}$ions of 16:0/16:0-PC $(\mathrm{m} / \mathrm{z}$ 735.6) is shown in Panel (c).

temperature of the heated capillary was $250{ }^{\circ} \mathrm{C}$. The [M $+\mathrm{Li}^{+}$ions were selected in the first quadrupole (Q1), collided with Ar (2.3 mTorr) in the rf-only second quadrupole (Q2) using a collision energy of 30-32 eV and analyzed in the third quadrupole (Q3). For source CAD tandem mass spectrometry of source-generated fragment ions (source CAD-MS ${ }^{2}$ ), a voltage equivalent to that used in the product-ion spectra $(30-32 \mathrm{eV})$ was applied to the rf-only ion-transmission octapole to generate fragment ions, which were selected in the Q1 and collided with Ar (2.3 mTorr) in the Q2, where the offset voltage was set at $10 \mathrm{~V}$. Both Q1 and Q3 were tuned to unit mass resolution and scanned at a rate of 3 $\mathrm{s} / \mathrm{scan}$. The mass spectra were accumulated in the profile mode, typically for 1-5 min was employed for a tandem mass spectrum.

\section{Results and Discussion}

\section{CAD Tandem Mass Spectrometry of the [M+ $\mathrm{H}^{+}$Ions of Diacylphosphatidylcholine}

Under low-energy CAD, the $[\mathrm{M}+\mathrm{H}]^{+}$ions of diacylphosphatidylcholines yield a prominent ion at $\mathrm{m} / \mathrm{z}$ 184, representing a protonated phosphocholine, and ions regarding to the structural information are of low abundance. As shown in Figure 1, the product-ion spectra of the $[\mathrm{M}+\mathrm{H}]^{+}$ions of $16: 0 / 18: 1-\mathrm{PC}$ at $\mathrm{m} / \mathrm{z}$
760.6 (Figure 1a) and of 16:0/16:0-PC (Figure $1 \mathrm{~b}$ ) at $\mathrm{m} / \mathrm{z}$ 734.6 are dominated by the $m / z 184$ ion. The origin of this ion was thought to derive from the fragmentation process involving the participation of the hydrogens on the glycerol backbone of a PC molecule [5]. However, an analogous ion at $\mathrm{m} / \mathrm{z} 185$ was observed for the perdeuterated $\mathrm{d}_{31}-16: 0 / \mathrm{d}_{31}-16: 0-\mathrm{PC}$ at $\mathrm{m} / z$ 796.9 (Figure 1d), $\mathrm{d}_{27}-14: 0 / \mathrm{d}_{27}-14: 0-\mathrm{PC}$ at $m / z 732.8$ (Figure $1 \mathrm{e}$ ), and $\mathrm{d}_{31}-16: 0 / \mathrm{d}_{33}-18: 1-P C$ at $m / z 824.9$ (data not shown). These results indicate that the hydrogen in the fatty acid chain rather than in the glycerol backbone participated in the cleavage.

The hydrogen participating in the formation of the $m / z 184$ (phosphocholine) ion most likely arises from the $\alpha$-hydrogens of the fatty acyl chain. This is supported by the product-ion spectrum of the $[\mathrm{M}+\mathrm{H}]^{+}$ ion of $\mathrm{d}_{27}-14: 0 / \mathrm{d}_{26}-14: 0-\mathrm{PC}$ at $m / z 731.8$ (Figure $1 \mathrm{f}$ ), in which one of the $\alpha$-hydrogens of the fatty acyl substituent at $s n-2$ is not deuterated. The spectrum contains ions at $m / z 185$ and 184, indicating that the $\alpha$-hydrogens, indeed involve in the ion formation.

The abundance ratio of the two ions $(185 / 184)$ observed for $\mathrm{d}_{27}-14: 0 / 14: 0-\mathrm{PC}$ is $2 / 3$, while the ratio is $3 / 2$ for 14:0/ $\mathrm{d}_{27}-14: 0-\mathrm{PC}$ (data not shown). The preferential occurrence of the $m / z 184$ ion over $m / z 185$ ion in the spectrum of the former and the greater abundance of the $m / z 185$ ion than the $m / z 184$ ion observed in the 
a)

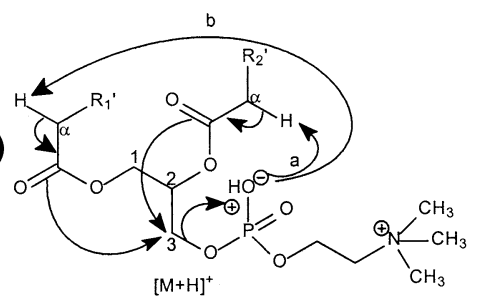

b)

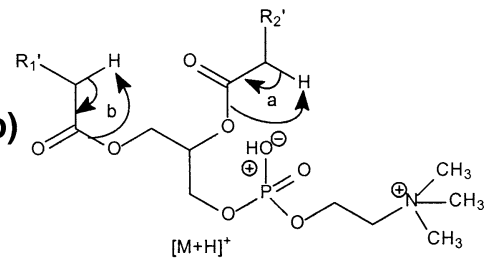

c)

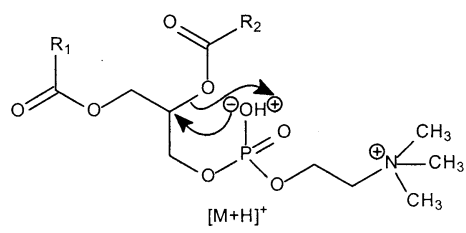

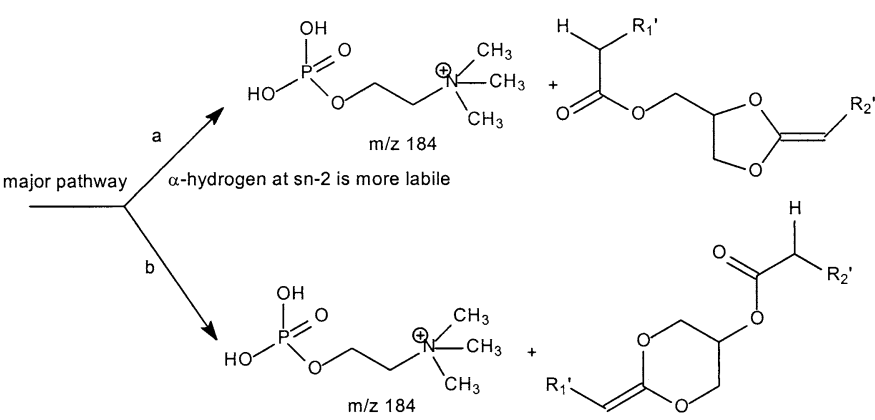
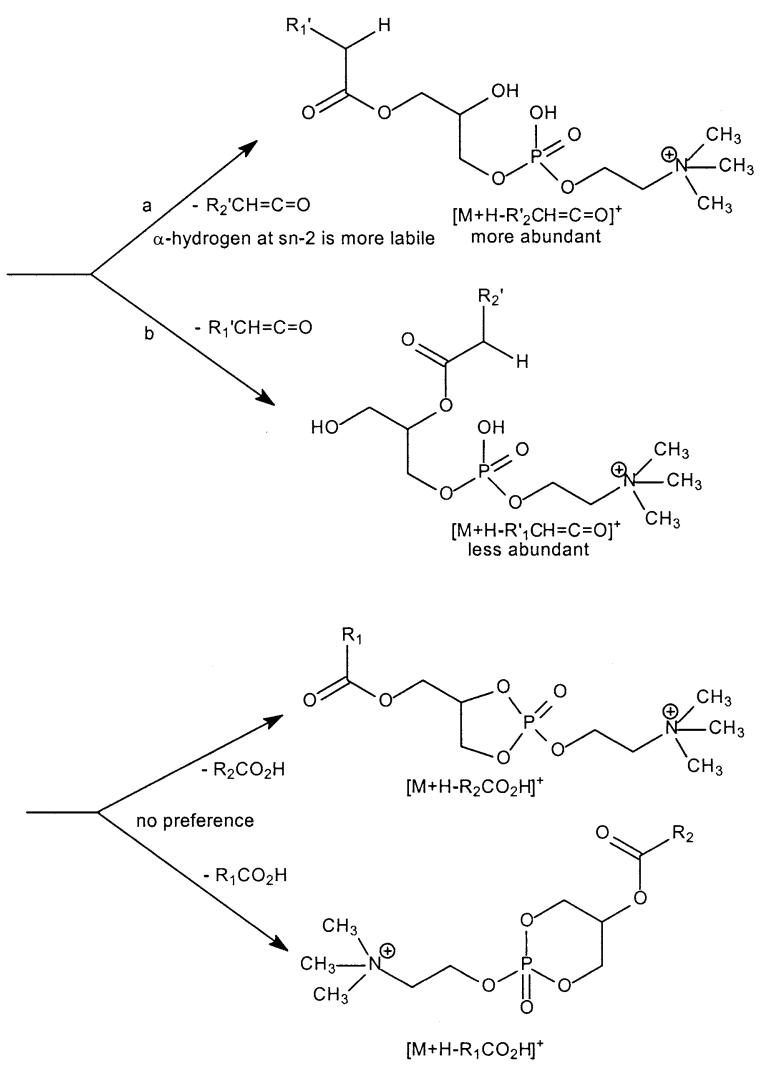

Scheme 2 spectrum of the latter indicate that the $\alpha$-hydrogens of the fatty acyl at $s n-2$ are more labile. The participation of the $\alpha$-hydrogen at $s n-2$ probably forms the protonated phosphocholine ion and a 5-member cyclic neutral species (route a), while a 6-member cyclic molecule and a phosphocholine ion are formed by the participation of the $\alpha$-hydrogen at $s n-1$ (route b), (Scheme $2 \mathbf{a}$ ). The results are also in accord with the observation of the greater abundance of the $m / z 496$ ion ([M + $\left.\left.\mathrm{H}_{-} \mathrm{R}_{2}{ }^{\prime} \mathrm{CH}=\mathrm{C}=\mathrm{O}\right]^{+}\right)$than that of the $m / z 522$ ion $([\mathrm{M}+$ $\mathrm{H}-\mathrm{R}_{1}{ }^{\prime} \mathrm{CH}=\mathrm{C}=\mathrm{O}^{+}$) (Figure 1a), arising from losses of the fatty acyl at $s n-2$ and $s n-1$ as a ketene, respectively (Scheme $2 \mathbf{b}$ ). The $\alpha$-hydrogens also involve in the major fragmentation processes for the lithiated PC following CAD (Discuss later).

In addition to the major ion of $m / z$ 184, the production spectrum of 16:0/16:0-PC (Figure 1b), contains ions at $m / z 478\left(\left[\mathrm{M}+\mathrm{H}-\mathrm{C}_{15} \mathrm{H}_{31} \mathrm{CO}_{2} \mathrm{H}\right]^{+}\right)$and $496([\mathrm{M}+$ $\left.\mathrm{H}-\mathrm{C}_{15} \mathrm{H}_{31} \mathrm{CH}=\mathrm{C}=\mathrm{O}\right]^{+}$), arising from elimination of the fatty acid moieties as a free acid and as a ketene, respectively. The analogous ions at $m / z 509([\mathrm{M}+$ $\left.\left.\mathrm{H}-\mathrm{C}_{15} \mathrm{D}_{31} \mathrm{CO}_{2} \mathrm{H}\right]^{+}\right)$and $528\left(\left[\mathrm{M}+\mathrm{H}-\mathrm{C}_{14} \mathrm{D}_{29} \mathrm{CD}=\mathrm{C}=\mathrm{O}\right]^{+}\right)$ were also observed for $d_{31}-16: 0 / d_{31}-16: 0-P C$ (Figure 1c), indicating that the loss of free fatty acid involves the $\mathrm{H}^{+}$ ion that protonated the molecule to a $[\mathrm{M}+\mathrm{H}]^{+}$, rather than a $\alpha$-hydrogen (Scheme 2c). This is further supported by the presence of $m / z \quad 478$ ([M + D- $\left.\mathrm{C}_{15} \mathrm{H}_{31} \mathrm{CO}_{2} \mathrm{D}\right]^{+}$) in the product-ion spectrum of the $[\mathrm{M}+\mathrm{D}]^{+}$ion of 16:0/16:0-PC at $\mathrm{m} / \mathrm{z} 735.6$ (Figure $1 \mathrm{c}$ ), generated by electrospray ionizing the sample that has been acidified with $\mathrm{CH}_{3} \mathrm{CO}_{2} \mathrm{D}$ in $\mathrm{CH}_{3} \mathrm{OD}$. The results are also consistent with the observation of the $\mathrm{m} / \mathrm{z} 477$ $\left(\left[\mathrm{M}+\mathrm{H}-\mathrm{C}_{13} \mathrm{D}_{27} \mathrm{CO}_{2} \mathrm{H}\right]^{+}\right)$ion in the product-ion spectrum of $\mathrm{d}_{27}-14: 0 / \mathrm{d}_{27}-14$ :0-PC (Figure $1 \mathrm{~d}$ ), and of both 

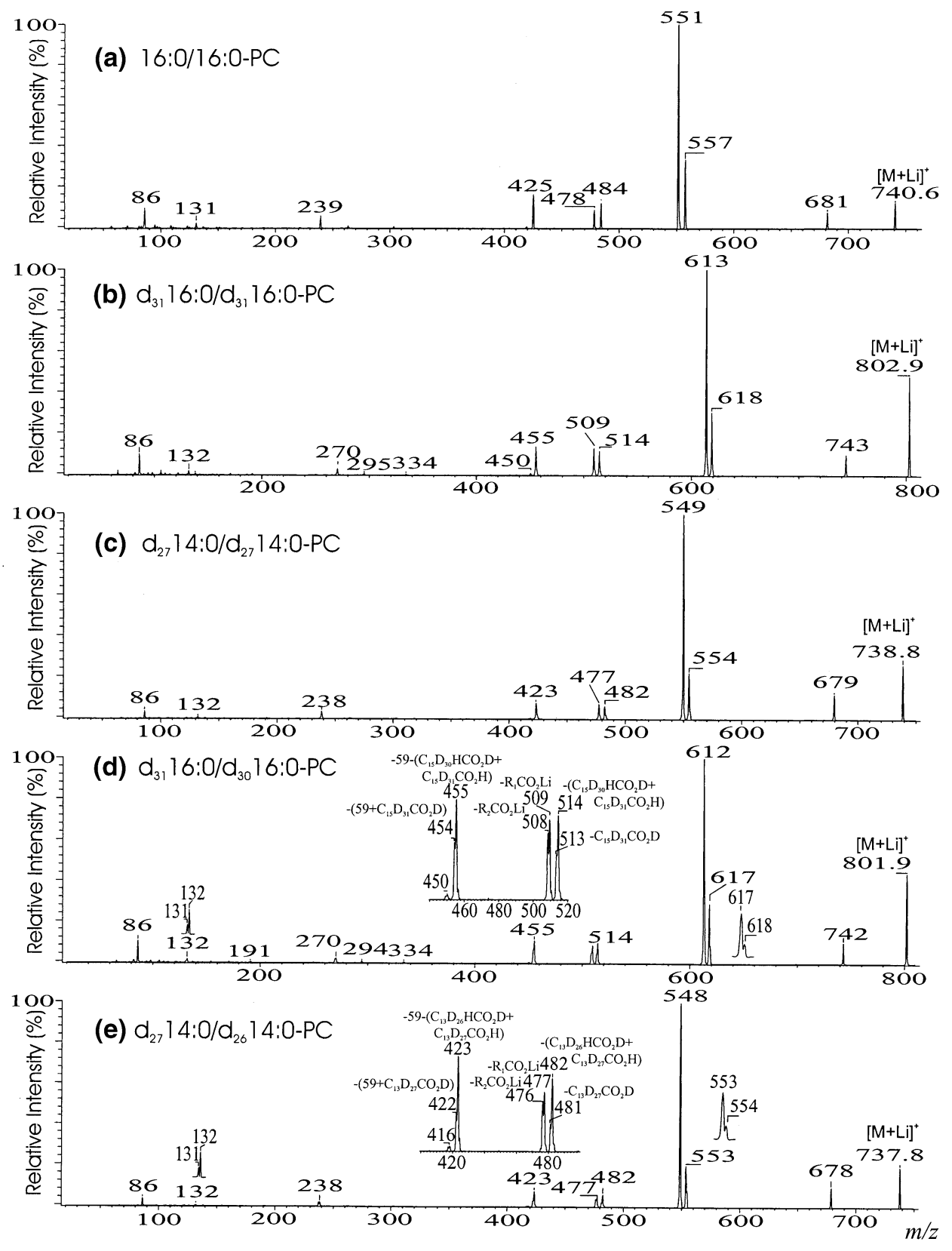

Figure 2. The product-ion spectra of the $\left[\mathrm{M}+\mathrm{Li}^{+}\right.$ions of (a) 16:0/16:0-PC $(\mathrm{m} / \mathrm{z}$ 740.6), (b) $\mathrm{d}_{31}-16: 0 / \mathrm{d}_{31}-16: 0-\mathrm{PC}\left(\mathrm{m} / \mathrm{z}\right.$ 802.9), (c) $\mathrm{d}_{27}-14: 0 / \mathrm{d}_{27}-14: 0-\mathrm{PC}(\mathrm{m} / \mathrm{z} 738.8),(\mathbf{d}) \mathrm{d}_{31}-16: 0 / \mathrm{d}_{30}-16: 0-\mathrm{PC}(\mathrm{m} / \mathrm{z}$ 801.9), and (e) $\mathrm{d}_{27}-14: 0 / \mathrm{d}_{26}-14: 0-\mathrm{PC}(\mathrm{m} / \mathrm{z} 737.8)$.

the $m / z 477\left(\left[\mathrm{M}+\mathrm{H}-\mathrm{C}_{13} \mathrm{D}_{27} \mathrm{CO}_{2} \mathrm{H}\right]^{+}\right)$and $m / z 476([\mathrm{M}+$ $\left.\mathrm{H}-\mathrm{C}_{13} \mathrm{D}_{26} \mathrm{HCO}_{2} \mathrm{H}\right]^{+}$) ions in the product-ion spectrum of $\mathrm{d}_{27}-14: 0 / \mathrm{d}_{26}-14: 0$-PC (Figure 1f).

\section{CAD Tandem Mass Spectrometry of the [M+ $\mathrm{Li}^{+}$Ions of Diacylphosphatidylcholines}

As shown in Figure 2a, the product-ion spectrum of the $\left[\mathrm{M}+\mathrm{Li}^{+}\right.$ion of 16:0/16:0-PC at $\mathrm{m} / \mathrm{z} 740.6$ contains prominent ions at $\mathrm{m} / \mathrm{z} 557\left([\mathrm{M}+\mathrm{Li}-183]^{+}\right)$and 551 $\left([\mathrm{M}+\mathrm{Li}-189]^{+}\right)$. The pathways previously proposed for formation of these two ions involve an initial loss of trimethylamine $\left([\mathrm{M}+\mathrm{Li}-59]^{+}\right)$, followed by an additional loss of $O, O^{\prime}$-dimethylenephosphoric acid (124 Da) or lithium $O, O^{\prime}$-dimethylenephosphate $(130 \mathrm{Da})$. This fragmentation process also results in $\mathrm{m} / \mathrm{z} 131$, corresponding to a lithiated $\mathrm{O}, \mathrm{O}^{\prime}$-dimethylenephosphoric acid ion. The hydrogens attached to $\mathrm{C} 2$ or $\mathrm{C} 3$ of the glycerol backbone were thought to involve in the loss of O,O'-dimethylenephosphoric acid [6, 7]. However, the analogous ions at $m / z 618\left([\mathrm{M}+\mathrm{Li}-184]^{+}\right)$and $613([\mathrm{M}$ + Li-189] $\left.^{+}\right)$, along with the $m / z 132$ ion were observed for the $[\mathrm{M}+\mathrm{Li}]^{+}$ion of $\mathrm{d}_{31}-16: 0 / \mathrm{d}_{31}-16: 0-\mathrm{PC}$ at $\mathrm{m} / \mathrm{z}$ 802.9 (Figure $2 \mathrm{~b}$ ). These results indicate that formation 

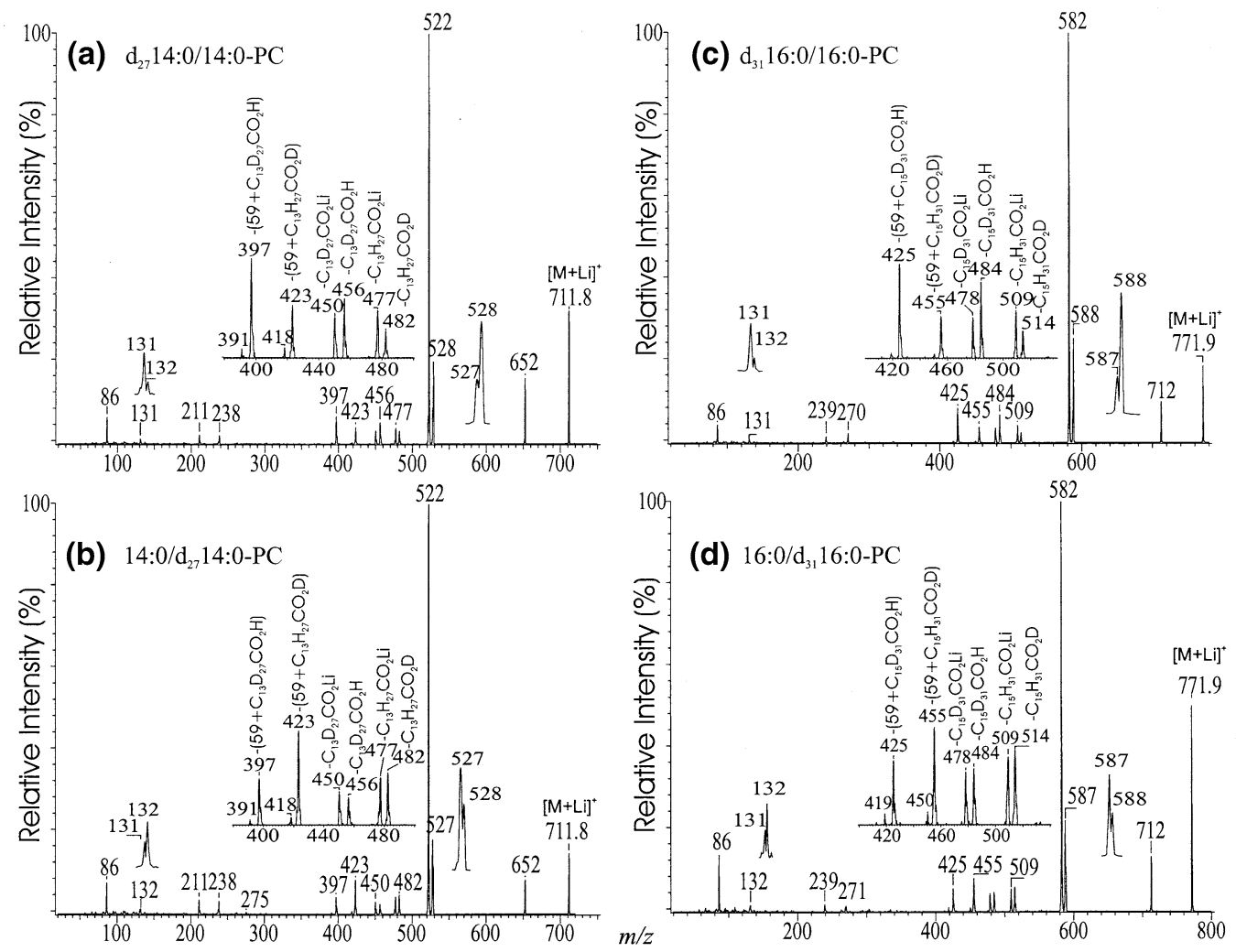

Figure 3. The product-ion spectra of the $[\mathrm{M}+\mathrm{Li}]^{+}$ions of (a) $\mathrm{d}_{27}-14: 0 / 14: 0-\mathrm{PC}(\mathrm{m} / \mathrm{z} 711.8),(\mathbf{b})$ 14:0/ $\mathrm{d}_{27}-14: 0-\mathrm{PC}(\mathrm{m} / \mathrm{z} 711.8)$, (c) $\mathrm{d}_{31}-16: 0 / 16: 0-\mathrm{PC}(\mathrm{m} / \mathrm{z} 771.9)$, and (d) $16: 0 / \mathrm{d}_{31}-16: 0-\mathrm{PC}(\mathrm{m} / \mathrm{z} 771.9)$.

of $\mathrm{m} / \mathrm{z} 618$ by loss of 184 includes a deuterium, most likely arising from the $\alpha$-hydrogen at the fatty acyl chain. The loss is consistent with the mass shift $(1 \mathrm{Da})$ observed for the lithiated $O, O^{\prime}$-dimethylenephosphoric acid ion at $\mathrm{m} / \mathrm{z}$ 132. The product-ion spectra arising from $\mathrm{d}_{27^{2}}-14: 0 / \mathrm{d}_{27^{-}}-14: 0-\mathrm{PC}$ (Figure $2 \mathrm{c}$ ) and $\mathrm{d}_{31^{-}}-16: 0 / \mathrm{d}_{33^{-}}$ 18:1-PC (data not shown) also contain both the [M + $\mathrm{Li}-184]^{+}$and $\mathrm{m} / \mathrm{z} 132$ ions. The participation of the $\alpha$-hydrogens of the fatty acyl substituent for the loss is established by the findings that both the $m / z 617$ ([M + $\left.\mathrm{Li}-184]^{+}\right)$and $m / z 618\left([\mathrm{M}+\mathrm{Li}-183]^{+}\right)$ions, along with $\mathrm{m} / \mathrm{z} 132$ and 131 are present in the product-ion spectrum of $\mathrm{d}_{31}-16: 0 / \mathrm{d}_{30}-16: 0-\mathrm{PC}$ at $\mathrm{m} / \mathrm{z} 801.9$ (Figure $2 \mathrm{~d}$ ), in which one of the $\alpha$-deuterium at $s n-2$ of the fatty acyl is replaced by a hydrogen. Similar results were also observed for $\mathrm{d}_{27}-14: 0 / \mathrm{d}_{26}-14: 0-P C$ at $m / z 737.8$ (Figure 2e).

Both the $[\mathrm{M}+\mathrm{Li}-184]^{+}$ion at $m / z 527$ and the $[\mathrm{M}+$ $\mathrm{Li}-183]^{+}$ion at $\mathrm{m} / \mathrm{z} 528$, along with the lithiated $O, \mathrm{O}^{\prime}-$ dimethylenephosphoric acid ions at $\mathrm{m} / \mathrm{z} 131$ and 132 were observed for the lithiated $\mathrm{d}_{27}-14: 0 / 14: 0-\mathrm{PC}$ at $\mathrm{m} / \mathrm{z}$ 711.8 (Figure 3a). The abundances of the $\mathrm{m} / \mathrm{z} 528$ and 131 ions are, respectively, greater than those of $\mathrm{m} / \mathrm{z} 527$ and 132, suggesting that the participation of the $\alpha$-hydrogen of the fatty acyl at $s n-2$ to expel the $O, O^{\prime}-$ dimethylenephosphoric acid is a more favorable pathway. The result may also indicate that the $\alpha$-hydrogens of the fatty acyl substituent at $s n-2$ are more labile than those at $s n-1$. This is further supported by the observa- tion of the reversed abundances of the above ion-pairs in the product-ion spectrum of the lithiated $14: 0 / \mathrm{d}_{27^{-}}$ 14:0-PC at $\mathrm{m} / \mathrm{z} 711.8$ (Figure 3b). Similar results were also observed for another set of the lithiated $\mathrm{d}_{31}-16: 0$ / 16:0-PC (Figure 3c) and 16:0/ $\mathrm{d}_{31}-16: 0-\mathrm{PC}$ (Figure 3d) isomers at $\mathrm{m} / \mathrm{z} 771.9$. The proposed fragmentation pathways for formation of the $[\mathrm{M}+\mathrm{Li}-183]^{+}$ions are depicted in Scheme 3a.

As previously reported by us, product-ion spectra of the $[\mathrm{M}+\mathrm{Li}]^{+}$ions of diacylphosphatidylcholines provide structural information that identifies and locate the fatty acid substituents in the glycerol backbone [7]. Among the ions that permit the structural identification are $\left[\mathrm{M}+\mathrm{Li}-\mathrm{R}_{x} \mathrm{CO}_{2} \mathrm{H}\right]^{+}$and $\left[\mathrm{M}+\mathrm{Li}-59-\mathrm{R}_{x} \mathrm{CO}_{2} \mathrm{H}\right]^{+}(x=$ $1,2)$ ions. As shown in Figure $3 \mathrm{a}$, the $[\mathrm{M}+\mathrm{Li}-$ $\left.\mathrm{R}_{1} \mathrm{CO}_{2} \mathrm{H}\right]^{+}$and $\left[\mathrm{M}+\mathrm{Li}-\mathrm{R}_{2} \mathrm{CO}_{2} \mathrm{H}\right]^{+}$ions were observed at $\mathrm{m} / \mathrm{z} 456 \quad\left(711-\mathrm{C}_{13} \mathrm{D}_{27} \mathrm{CO}_{2} \mathrm{H}\right)$ and $\mathrm{m} / \mathrm{z} 482$ (711$\left.\mathrm{C}_{13} \mathrm{H}_{27} \mathrm{CO}_{2} \mathrm{D}\right)$, respectively. The former ion is more abundant than the latter; the $\left[\mathrm{M}+\mathrm{Li}-59-\mathrm{R}_{1} \mathrm{CO}_{2} \mathrm{H}\right]^{+}$ion at $\mathrm{m} / \mathrm{z} 397\left(652-\mathrm{C}_{13} \mathrm{D}_{27} \mathrm{CO}_{2} \mathrm{H}\right)$ is also more abundant than the $\left[\mathrm{M}+\mathrm{Li}-59-\mathrm{R}_{2} \mathrm{CO}_{2} \mathrm{H}\right]^{+}$ion at $\mathrm{m} / \mathrm{z} 423$ (652$\mathrm{C}_{13} \mathrm{H}_{27} \mathrm{CO}_{2} \mathrm{D}$ ). These results are consistent with the suggestions that the $\alpha$-hydrogens of the fatty acyl substituent at $s n-2$ are more labile and preferentially participate in the formation of the $\mathrm{m} / \mathrm{z} 456$ (711$\left.\mathrm{C}_{13} \mathrm{D}_{27} \mathrm{CO}_{2} \mathrm{H}\right)$ and $\mathrm{m} / \mathrm{z} 397\left(652-\mathrm{C}_{13} \mathrm{D}_{27} \mathrm{CO}_{2} \mathrm{H}\right)$ ions by loss of $\mathrm{C}_{13} \mathrm{D}_{27} \mathrm{CO}_{2} \mathrm{H}$, whereas the $\alpha$-deuteriums of the fatty acyl substituent at $s n-1$ are less labile and are responsible for formation of $\mathrm{m} / z 482\left(711-\mathrm{C}_{13} \mathrm{H}_{27} \mathrm{CO}_{2} \mathrm{D}\right)$ 


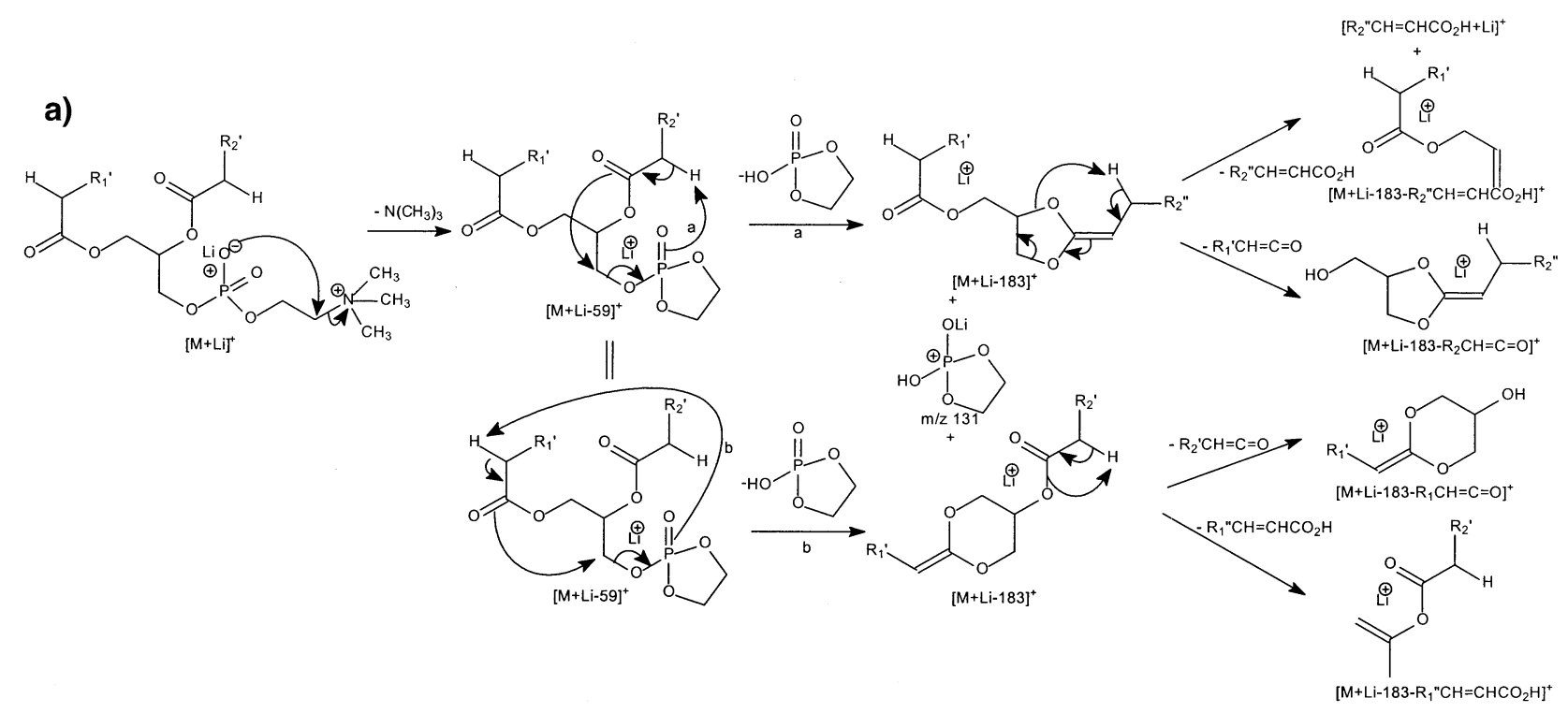

b)

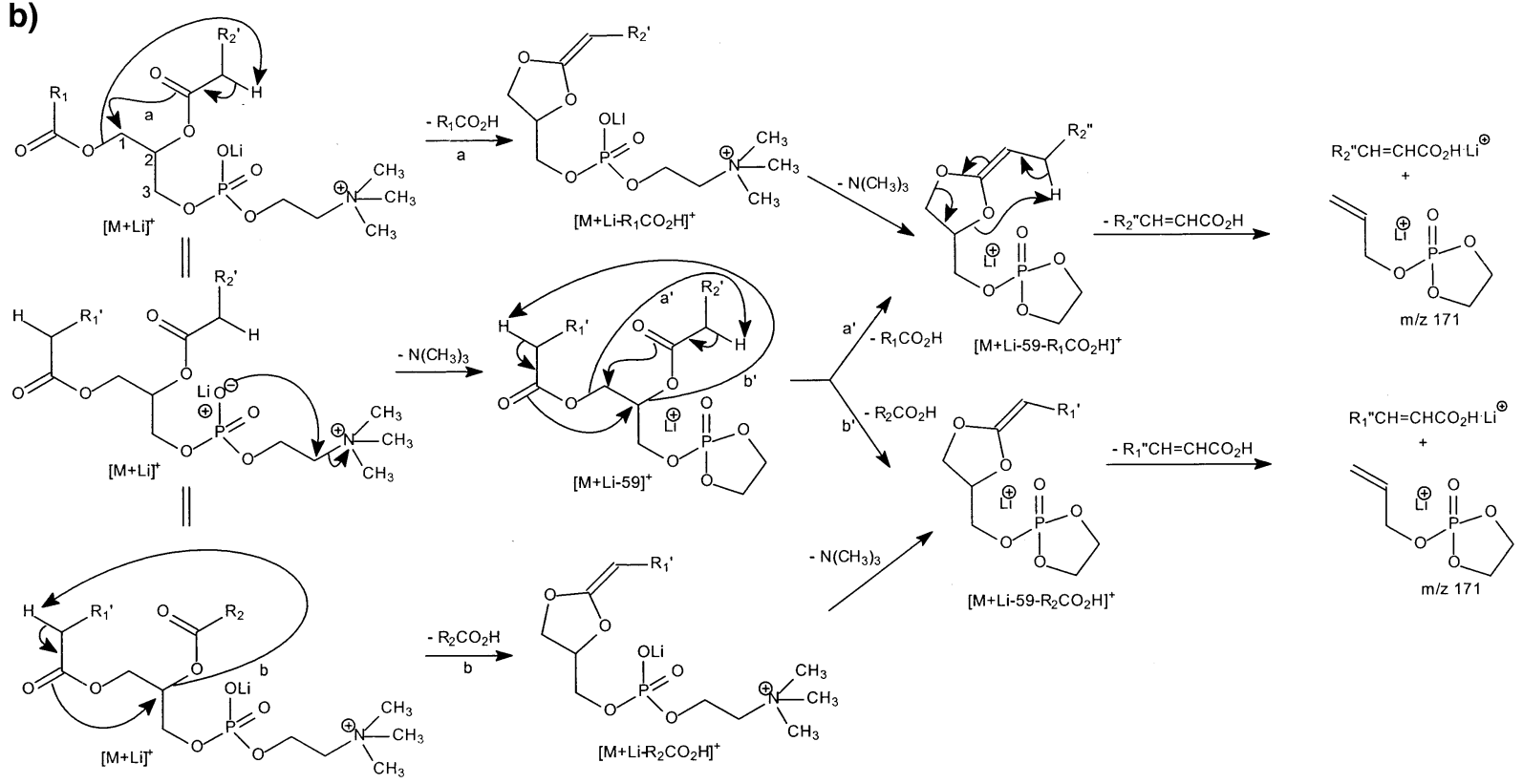

c)

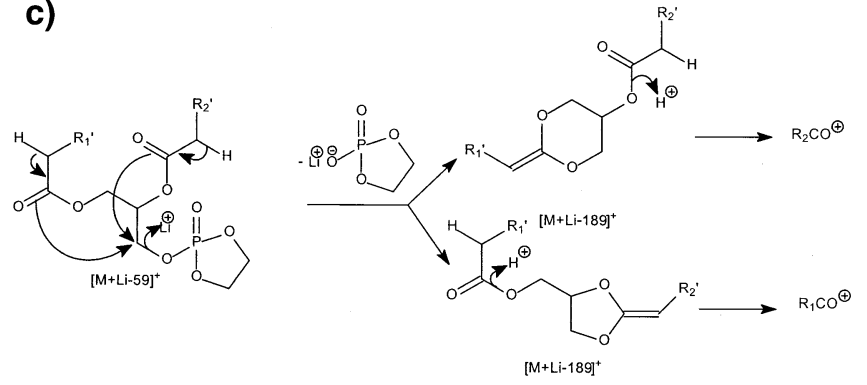

Scheme 3

and $m / z 423\left(652-\mathrm{C}_{13} \mathrm{H}_{27} \mathrm{CO}_{2} \mathrm{D}\right)$ ions by eliminating the fatty acid moiety at $s n-2$. This preferential loss of $\mathrm{C}_{13} \mathrm{D}_{27} \mathrm{CO}_{2} \mathrm{H}\left(\mathrm{R}_{1} \mathrm{CO}_{2} \mathrm{H}\right)$ over $\mathrm{C}_{13} \mathrm{H}_{27} \mathrm{CO}_{2} \mathrm{D}\left(\mathrm{R}_{2} \mathrm{CO}_{2} \mathrm{H}\right)$ results in a product-ion spectrum, by which the fatty acid substituents in glycerol backbone can be easily assigned. There is no appreciable difference in the abundances of the ions at $\mathrm{m} / \mathrm{z} 477\left(711-\mathrm{C}_{13} \mathrm{H}_{27} \mathrm{CO}_{2} \mathrm{Li}\right)$ and $450\left(711-\mathrm{C}_{13} \mathrm{D}_{27} \mathrm{CO}_{2} \mathrm{Li}\right)$, arising from losses of 


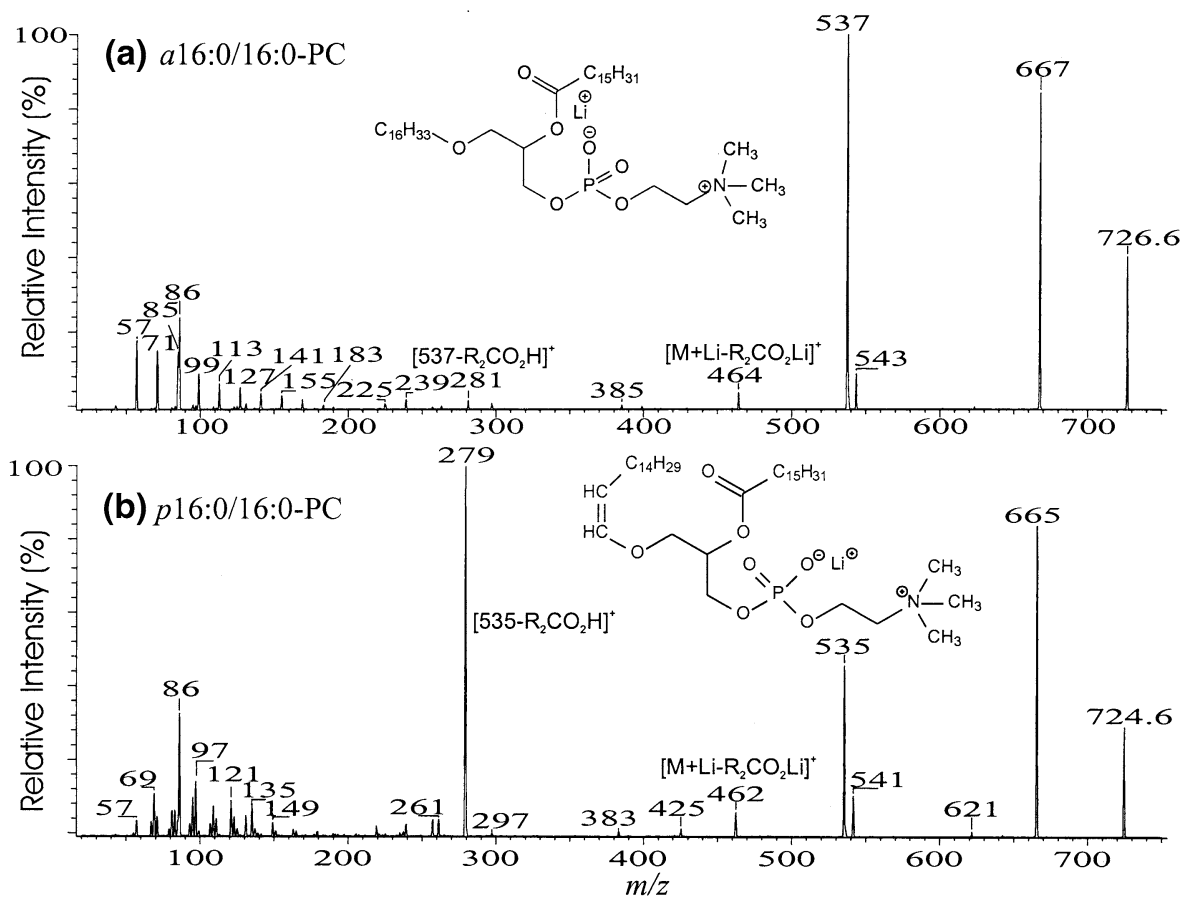

Figure 4. The product-ion spectra of the $[\mathrm{M}+\mathrm{Li}]^{+}$ions of (a) $a 16: 0 / 16: 0-\mathrm{PC}(\mathrm{m} / z$ 726.6), and (b) p16:0/16:0-PC ( $m / z$ 724.6).

$\mathrm{R}_{2} \mathrm{CO}_{2} \mathrm{Li}$ and $\mathrm{R}_{1} \mathrm{CO}_{2} \mathrm{Li}$ that involve $\mathrm{Li}^{+}$ion, respectively. This result is in accord with the findings that the abundances of the $m / z 504\left(760-\mathrm{R}_{1} \mathrm{CO}_{2} \mathrm{H}\right)$ and $m / z 478$ (760- $\mathrm{R}_{2} \mathrm{CO}_{2} \mathrm{H}$ ) ions deriving from loss of fatty acid moieties involving $\mathrm{H}^{+}$(protonated) ion instead of the $\alpha$-hydrogens are nearly identical for the $[\mathrm{M}+\mathrm{H}]^{+}$ion of 16:0/18:1-PC (Figure 1a). Thus, ions arising from these losses may not reflect the position of the fatty acid substituents. The preferential losses of $\mathrm{R}_{1} \mathrm{CO}_{2} \mathrm{H}$ over $\mathrm{R}_{2} \mathrm{CO}_{2} \mathrm{H}$ were further confirmed by the product-ion spectrum of $14: 0 / d_{27}-14: 0-P C$ (Figure $3 b$ ), which contains a similar ion profile consisting of the abundances of $\mathrm{m} / \mathrm{z} 482\left(\left[711-\mathrm{C}_{13} \mathrm{H}_{27} \mathrm{CO}_{2} \mathrm{D}\left(\mathrm{R}_{1} \mathrm{CO}_{2} \mathrm{H}\right)\right]\right)>\mathrm{m} / \mathrm{z} 456$ ([711- $\left.\left.\mathrm{C}_{13} \mathrm{D}_{27} \mathrm{CO}_{2} \mathrm{H}\left(\mathrm{R}_{2} \mathrm{CO}_{2} \mathrm{H}\right)\right]\right)$ and $\mathrm{m} / z 423\left(\left[652-\mathrm{C}_{13} \mathrm{H}_{27}\right.\right.$ $\left.\left.\mathrm{CO}_{2} \mathrm{D}\left(\mathrm{R}_{1} \mathrm{CO}_{2} \mathrm{H}\right)\right]\right)>\mathrm{m} / \mathrm{z} 397\left(\left[652-\mathrm{C}_{13} \mathrm{D}_{27} \mathrm{CO}_{2} \mathrm{H}\left(\mathrm{R}_{2} \mathrm{CO}_{2}\right.\right.\right.$ $\mathrm{H})$ ]). Similar results were also observed for another set of the lithiated $\mathrm{d}_{31}-16: 0 / 16: 0-\mathrm{PC}$ (Figure 3c) and 16:0/ $\mathrm{d}_{31}-16: 0-\mathrm{PC}$ (Figure $3 \mathrm{~d}$ ) isomers.

The pathways previously proposed for yielding the above ions were rationalized that expulsion of $\mathrm{R}_{2} \mathrm{CO}_{2} \mathrm{H}$ involves the glycerol hydrogens residing at $\mathrm{C} 1$ or $\mathrm{C} 3$ (four available hydrogens), while loss of $\mathrm{R}_{1} \mathrm{CO}_{2} \mathrm{H}$ involves the single methine hydrogen residing at $\mathrm{C} 2$ of the glycerol backbone (Scheme 1b) [5, 7, 9]. However, these pathways would contradict with the fact that ions arising from $\mathrm{R}_{1} \mathrm{CO}_{2} \mathrm{H}$ loss (i.e., the $\left[\mathrm{M}+\mathrm{Li}-\mathrm{R}_{1} \mathrm{CO}_{2} \mathrm{H}\right]^{+}$ and $\left[\mathrm{M}+\mathrm{Li}-59-\mathrm{R}_{1} \mathrm{CO}_{2} \mathrm{H}\right]^{+}$ions) are more abundant than those arising from $\mathrm{R}_{2} \mathrm{CO}_{2} \mathrm{H}$ loss (i.e., the $[\mathrm{M}+$ $\left.\mathrm{Li}-\mathrm{R}_{1} \mathrm{CO}_{2} \mathrm{H}\right]^{+}$and $\left[\mathrm{M}+\mathrm{Li}-59-\mathrm{R}_{1} \mathrm{CO}_{2} \mathrm{H}\right]^{+}$ions). The fragmentation processes also contradict with the observation of the mass shift of the corresponding ions deriving from the deuterium-labeling analogs. Thus, the most likely pathway for the acid loss involves the two adjacent fatty acyl chains, in which one releases a $\alpha$-hydrogen and renders a nucleophilc attack on the $\mathrm{C} 1$ (routes a and a') or C2 (routes b and b') of the glycerol backbone to expel a $\mathrm{R}_{1} \mathrm{CO}_{2} \mathrm{H}$ or $\mathrm{R}_{2} \mathrm{CO}_{2} \mathrm{H}$ (Scheme $3 \mathbf{b}$ ). The preferential loss of $\mathrm{R}_{1} \mathrm{CO}_{2} \mathrm{H}$ over $\mathrm{R}_{2} \mathrm{CO}_{2} \mathrm{H}$ is attributable to the fact that the $\alpha$-hydrogens of the fatty acyl chain at $s n-2$ are more labile than those at $s n-1$. The more favorable loss of $\mathrm{R}_{1} \mathrm{CO}_{2} \mathrm{H}$ than $\mathrm{R}_{2} \mathrm{CO}_{2} \mathrm{H}$ has been previously reported for the lithiated and dilithiated ions of phophatidylethanolamine under low-energy CAD [14]. The fragmentation pathway may also account for the previous findings that ions arising from losses of $\mathrm{R}_{1} \mathrm{CO}_{2} \mathrm{H}\left(\left[\mathrm{M}+\mathrm{Li}-\mathrm{R}_{1} \mathrm{CO}_{2} \mathrm{H}\right]^{+}\right)$and $\mathrm{R}_{3} \mathrm{CO}_{2} \mathrm{H}([\mathrm{M}+\mathrm{Li}-$ $\left.\mathrm{R}_{3} \mathrm{CO}_{2} \mathrm{H}\right]^{+}$) are more abundant than that arising from $\mathrm{R}_{2} \mathrm{CO}_{2} \mathrm{H}$ loss $\left(\left[\mathrm{M}+\mathrm{Li}-\mathrm{R}_{2} \mathrm{CO}_{2} \mathrm{H}\right]^{+}\right)$for triacylglycerol [11].

CAD Tandem Mass Spectrometry of the [M+ $\mathrm{Li}^{+}$Ions of 1-O-alkyl-2-acyl-sn-glycero-3Phosphocholines (Plasmanylphosphocholines) and 1-O-alk-1'-enyl-2-acyl-sn-glycero-3Phosphocholines (Plasmalogens)

The apparent differences in the product-ion spectra of the $[\mathrm{M}+\mathrm{Li}]^{+}$ions of 1-O-alkyl-2-acyl-sn-glycero-3phosphocholines from those of diacyl-PCs are that the ion corresponding to $\left[\mathrm{M}+\mathrm{Li}-\mathrm{R}_{x} \mathrm{CO}_{2} \mathrm{H}\right]^{+}$is not present and the $\left[\mathrm{M}+\mathrm{Li}-59-\mathrm{R}_{x} \mathrm{CO}_{2} \mathrm{H}\right]^{+}$ion is of low abundance, while the $[\mathrm{M}+\mathrm{Li}-59]^{+}$ion becomes prominent. As shown in Figure $4 \mathrm{a}$, the $[\mathrm{M}+\mathrm{Li}]^{+}$ion of $a 16: 0 / 16: 0-\mathrm{PC}$ 

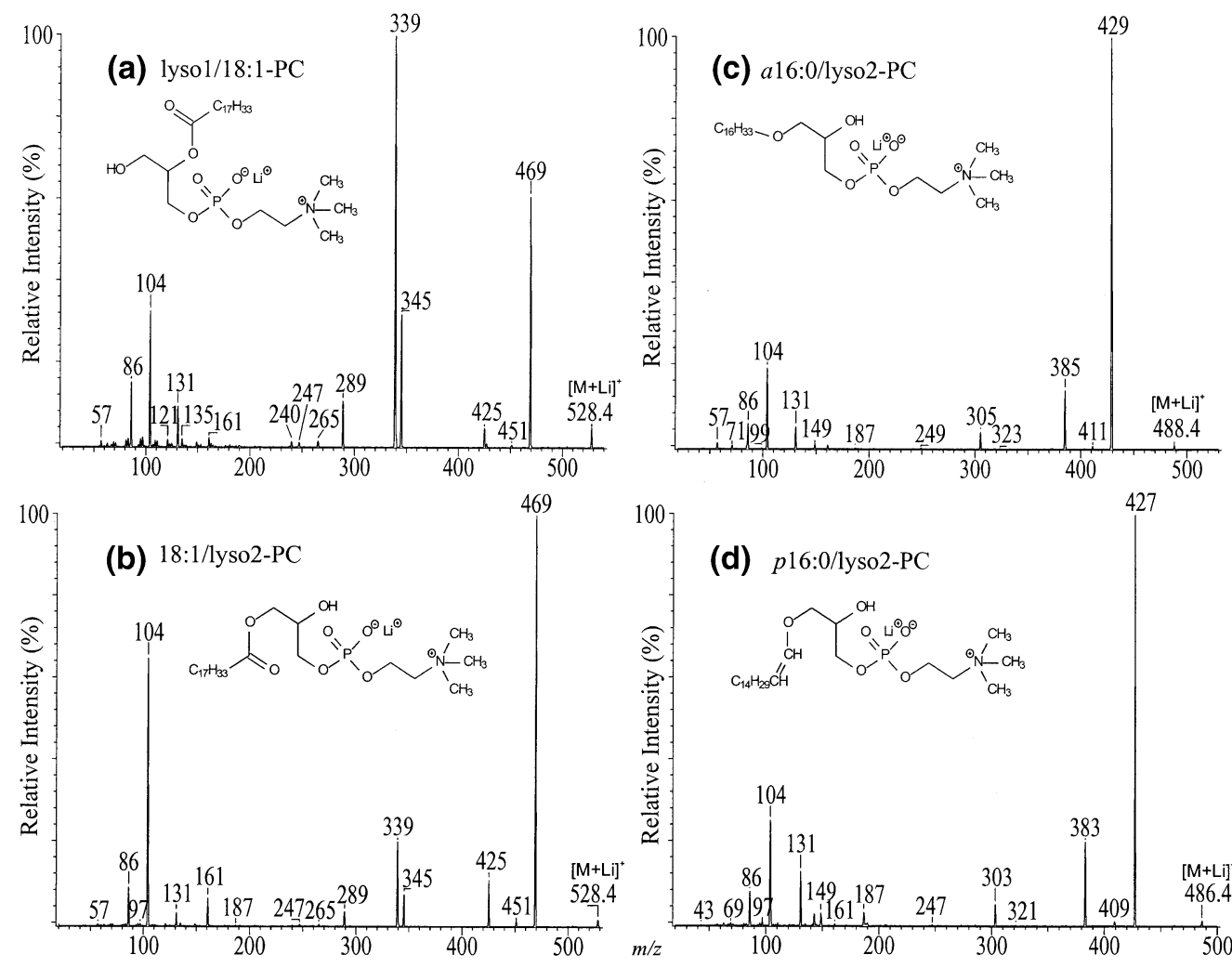

(d) $p 16: 0 / 1 y s o 2-\mathrm{PC}$
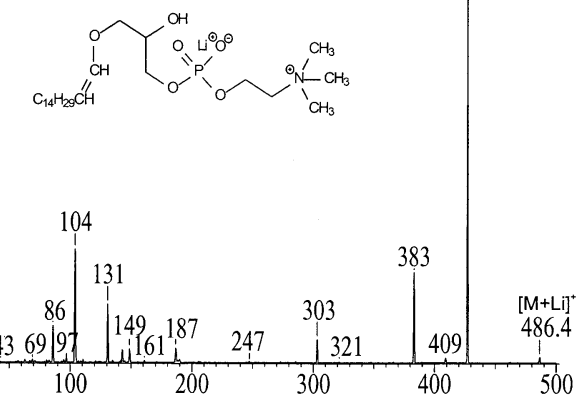

Figure 5. The product-ion spectra of the $[\mathrm{M}+\mathrm{Li}]^{+}$ions of (a) lyso1/18:1-PC $(\mathrm{m} / z$ 528.4), (b) 18:1/lyso2-PC ( $m / z$ 528.4), (c) a16:0/lyso2-PC ( $m / z ~ 488.4)$, and (d) $p 16: 0 / 1 y s o 2-P C ~(m / z ~ 486.4)$.

at $m / z 726.6$ yields prominent ions at $\mathrm{m} / \mathrm{z} 667([\mathrm{M}+$ Li-59 $\left.]^{+}\right), 543\left([\mathrm{M}+\mathrm{Li}-183]^{+}\right)$, and $537\left([\mathrm{M}+\mathrm{Li}-189]^{+}\right)$. The ions at $m / z 470\left(\left[\mathrm{M}+\mathrm{Li}^{-} \mathrm{C}_{15} \mathrm{H}_{31} \mathrm{CO}_{2} \mathrm{H}\right]^{+}\right)$and 411 $\left(\left[\mathrm{M}+\mathrm{Li}-59-\mathrm{C}_{15} \mathrm{H}_{31} \mathrm{CO}_{2} \mathrm{H}\right]^{+}\right)$, arising from loss of the sn-2 substituent as an acid, and $484\left(\left[\mathrm{M}+\mathrm{Li}^{-}\right.\right.$ $\left.\mathrm{C}_{16} \mathrm{H}_{33} \mathrm{OH}\right]^{+}$), corresponding to direct loss of the sn-1 substituent as an alkyl alcohol, are not present. The substitution of the $s n-1$ moiety with an alkyl group blocks the pathway that requires the $\alpha$-hydrogen of the $s n-1$ moiety for the $\mathrm{R}_{2} \mathrm{CO}_{2} \mathrm{H}$ loss (i.e., route $\mathrm{b}$, Scheme $3 b)$. Therefore, the $\left[\mathrm{M}+\mathrm{Li}_{-} \mathrm{C}_{15} \mathrm{H}_{31} \mathrm{CO}_{2} \mathrm{H}\right]^{+}$and $[\mathrm{M}+$ $\left.\mathrm{Li}-59-\mathrm{C}_{15} \mathrm{H}_{31} \mathrm{CO}_{2} \mathrm{H}\right]^{+}$ions were not observed. Whereas the absence of the $m / z 484$ ion $\left(\left[\mathrm{M}+\mathrm{Li}-\mathrm{R}_{1} \mathrm{OH}\right]^{+}\right)$may be attributable to the fact that expulsion of an alcohol via this fragmentation process is less achievable than loss of an acid. Indeed, the analogous ions at $m / z 468$ ([M + $\left.\left.\mathrm{Li}-\mathrm{C}_{15} \mathrm{H}_{31} \mathrm{CO}_{2} \mathrm{H}\right]^{+}\right)$and $484 \quad\left(\left[\mathrm{M}+\mathrm{Li}^{-}\right.\right.$ $\left.\mathrm{C}_{14} \mathrm{H}_{29} \mathrm{CH}=\mathrm{CHOH}\right]^{+}$) are also absent in the production spectrum of $p 16: 0 / 16: 0-\mathrm{PC}$ at $m / z 724.6$ (Figure $4 \mathrm{~b}$ ), a plasmalogen $\mathrm{PC}$, which possesses a 1-alk-1'-enyl. The lack of the $\alpha$-hydrogen at sn-1 may also account for the rise of the $\left([\mathrm{M}+\mathrm{Li}-59]^{+}\right)$ions at $m / z 667$ and 665 for a16:0/16:0-PC and $p 16: 0 / 16: 0-\mathrm{PC}$, respectively, which would have been significantly decreased by the further dissociation process that utilizes the $\alpha$-hydrogen at sn- 1 (i.e., route b', Scheme $\mathbf{3 b}$ ). The intensity of the $\mathrm{m} / \mathrm{z} 464$ ion $\left(\left[\mathrm{M}+\mathrm{Li}^{-} \mathrm{C}_{15} \mathrm{H}_{31} \mathrm{CO}_{2} \mathrm{Li}\right]^{+}\right.$) (Figure 4a) arising from loss of the $s n-2$ moiety as lithium palmitate is close to that of the analogous ions observed for 18:0/20:4-PC
(Figure 6a, $m / z 526$ and 506) and 16:0/18:1-PC (Figure $6 e, m / z 504$ and 478). The results suggest that the pathway leading to the $\mathrm{R}_{x} \mathrm{CO}_{2} \mathrm{Li}$ loss, which involves the $\mathrm{Li}^{+}$ion that cationizes the molecule to $[\mathrm{M}+\mathrm{Li}]^{+}$, is similar for the lithiated PC molecules possessing one or two fatty acyl group(s). Similar results were also observed for the product-ion spectrum arising from $p 16$ : 0/16:0-PC (Figure 4b), in which the $\alpha$-hydrogen is only present at $s n-2$ of the fatty acyl. The product-ion spectrum also contains a prominent ion at $\mathrm{m} / \mathrm{z} 279$ (535$\mathrm{C}_{15} \mathrm{H}_{31} \mathrm{CO}_{2} \mathrm{H}$ ), arising from dissociation of $\mathrm{m} / \mathrm{z} 535$ ([M $+[\mathrm{Li}-189]^{+}$) by loss of the $s n-2$ fatty acyl moiety (Figure $4 \mathrm{~b})$. The prominence of the $\mathrm{m} / \mathrm{z} 279$ ion ([M $+\mathrm{Li}-189-$ $\left.\mathrm{R}_{2} \mathrm{CO}_{2} \mathrm{H}\right]^{+}$) along with the decline of the $[\mathrm{M}+\mathrm{Li}-189]^{+}$ ion at $\mathrm{m} / \mathrm{z} 535$ resulting from the dissociation facilitate identification of plasmalogen PCs by tandem mass spectrometry and permit its differentiation from a plasmanyl PC [12].

\section{CAD Tandem Mass Spectrometry of the [M+ $\mathrm{Li}^{+}$Ions of Lysophosphatidylcholines}

The concept that the absence of the $\left[\mathrm{M}+\mathrm{Li}-\mathrm{R}_{x} \mathrm{CO}_{2} \mathrm{H}\right]^{+}$ ion is caused by the lack of the $\alpha$-hydrogen in either one of the radyl groups of a PC molecule is further evidenced by the product-ion spectra arising from the lithiated lysophophatidylcholines, in which either $s n-1$ or $s n-2$ moiety is substituted by a hydroxyl group. As 
shown in Figure 5a, the product-ion spectrum of the $[\mathrm{M}+\mathrm{Li}]^{+}$ion of lyso1/18:1-PC at $m / z 528.4$ is similar to that observed for $a 16: 0 / 16: 0-P C$ (Figure 4a). The abundances of the ions at $m / z 345\left([\mathrm{M}+\mathrm{Li}-183]^{+}\right)$and 339 $\left([\mathrm{M}+\mathrm{Li}-189]^{+}\right)$are close to those observed for a diacyl-PC. However, the $[\mathrm{M}+\mathrm{Li}-59]^{+}$ion at $m / z 469$ becomes abundant, and the $m / z 246([\mathrm{M}+\mathrm{Li}-$ $\left.\left.\mathrm{R}_{2} \mathrm{CO}_{2} \mathrm{H}\right]^{+}\right)$and $m / z 187\left(\left[\mathrm{M}+\mathrm{Li}-59-\mathrm{R}_{2} \mathrm{CO}_{2} \mathrm{H}\right]^{+}\right)$ions are not present. Both the lyso1/18:1-PC and $a 16: 0 / 16: 0-\mathrm{PC}$ share a structure that consists of a pair of $\alpha$-hydrogens at the $s n-2$ fatty acyl, and the $\alpha$-hydrogens at $s n-1$ are not present. Therefore, the resemblance in the production spectra between them is partially attributed to the fact that the major pathways leading to ion formations are initiated by releasing the $\alpha$-hydrogen of the fatty acyl at $s n-2$. In contrast, pathways leading to dissociation of the 18:1/lyso2-PC isomer are initiated by the less labile $\alpha$-hydrogens of the fatty acyl at $s n-1$. This fragmentation process results in a distinct product-ion spectrum featured by a prominent ion at $m / z 469$ ([M + $\mathrm{Li}^{-59]^{+}}{ }^{+}$, and by the less prominent ions at $m / z 345$ ([M $\left.+\mathrm{Li}-183]^{+}\right)$and $339\left([\mathrm{M}+\mathrm{Li}-189]^{+}\right)$(Figure 5b).

As noted earlier, further dissociation of the $[\mathrm{M}+$ Li-59] ${ }^{+}$ion with participation of the $\alpha$-hydrogens of the fatty acyl leads to formation of the $[\mathrm{M}+\mathrm{Li}-183]^{+}$and $[\mathrm{M}+\mathrm{Li}-189]^{+}$ions. Hence, the prominence of the $[\mathrm{M}+$ Li-59] ${ }^{+}$ion as observed for both the lithiated 18:1/ lyso2-PC and lyso1/18:1-PC is attributable to the fact that the fatty acyl substituent at $s n-1$ or $s n-2$ has been replaced by a hydroxyl, with which further dissociation of $[\mathrm{M}+\mathrm{Li}-59]^{+}$participated by the exchangeable hydrogen becomes less favorable. This fragmentation process has been supported by the deuterium-labeling analogs produced by H-D exchange [12]. The pathway leading to further dissociation of the $\left[\mathrm{M}+\mathrm{Li}_{-59}\right]^{+}$ion participated by the $\alpha$-hydrogens of the fatty acyl at $s n-1$ for $18: 1 /$ lyso2-PC is less favorable than that at $s n-2$ for lyso1/18:1-PC. These consecutive dissociation processes differentiated by the origins of the $\alpha$-hydrogen lead to the prominence of $m / z 339$ and to the decline of $\mathrm{m} / \mathrm{z} 469$ for lyso1/18:1-PC (Figure 5a), which can be easily distinguished from its 18:1/lyso2-PC counterpart that is featured by a prominent ion at $m / z 469$ ([M + Li-59] ${ }^{+}$), and by the less prominent ions at 339 ([M + Li-189] ${ }^{+}$) (Figure 5b). The differences between the product-ion spectra of the two isomers permit their distinction by tandem mass spectrometry $[12,13]$.

Both the $[\mathrm{M}+\mathrm{Li}]^{+}$ions of $a 16: 0 / 1 \mathrm{yso} 2-\mathrm{PC}$ at $\mathrm{m} / \mathrm{z}$ 488.4 (Figure $5 c$ ) and $p 16: 0 /$ lyso2-PC at $m / z 486.4$ (Figure $5 \mathrm{~d}$ ) yield product-ion spectra close to that observed for 18:1/lyso2-PC (Figure 5b). However, the $[\mathrm{M}+$ Li-189 ${ }^{+}$ions at $m / z 299\left([488-189]^{+}\right)$and $m / z 297([486-$ $\left.189]^{+}\right)$are absent in the product-ion spectra of $a 16: 0 /$ lyso2-PC and $p 16: 0 /$ lyso2-PC, respectively. The $[\mathrm{M}+$ Li-183 $]^{+}$ions at $m / z 305\left([488-183]^{+}\right)$for $a 16: 0 / 1 y s o 2-P C$, and at $m / z 303\left([486-183]^{+}\right)$for $p 16: 0 / 1 y s o 2-P C$ are of low abundance. These results are consistent with the notion that $\alpha$-hydrogens in the fatty acyl moieties participating in the formation of the above ions. The lack of $\alpha$-hydrogen in both the $s n-1$ and $s n-2$ moieties, as seen for the two compounds, hampers the dissociation process leading to $[\mathrm{M}+\mathrm{Li}-189]^{+}$from $[\mathrm{M}+\mathrm{Li}-59]^{+}$, and results in the drastic decline of the $[\mathrm{M}+\mathrm{Li}-189]^{+}$ ion and the prominence of the $[\mathrm{M}+\mathrm{Li}-59]^{+}$ion.

\section{The Fragmentation Pathways Confirmed by Source-CAD Tandem Mass Spectrometry}

As described earlier, loss of trimethylamine is the primary step leading to further degradation to $[\mathrm{M}+$ Li-189 $]^{+}$and $[\mathrm{M}+\mathrm{Li}-183]^{+}$. This process is supported by the source-CAD product-ion spectra of the $m / z 757$ $\left(\left[816-\mathrm{N}\left\{\mathrm{CH}_{3}\right\}_{3}\right]^{+}\right)$(Figure 6b) and $\mathrm{m} / \mathrm{z} \quad 707$ ([766$\left.\mathrm{N}\left(\mathrm{CH}_{3}\right)_{3}\right]^{+}$) (Figure 6f) ions. The former spectrum contains ions at $m / z 633$ and 627 , identical to those observed for 18:0/20:4-PC at $\mathrm{m} / \mathrm{z} 816.7$ (Figure 6a), the precursor ion which yields the $m / z 757$ ion by source-CAD, whereas the latter spectrum contains major ions identical to those arising from the lithiated 16:0/18:1-PC at $m / z 766.6$ (Figure $6 \mathrm{e}$ ). The $[\mathrm{M}+\mathrm{Li}-183]^{+}$ion at $m / z 633$ is more abundant than the $[\mathrm{M}+\mathrm{Li}-189]^{+}$ion at $m / z 627$ for 18:0/20:4-PC. However, a reversal of the abundances of the $[\mathrm{M}+\mathrm{Li}-183]^{+}$and $[\mathrm{M}+\mathrm{Li}-189]^{+}$ions were observed for PC consisting of diacyl fatty acyl substituents that are more saturated, such as 16:0/18: 1-PC (Figure 6e) (i.e., $m / z 583$ and 577), and 16:0/16: 0-PC (Figure $2 b$ ) (i.e., $m / z 557$ and 551). A unique ion at $m / z 341\left(\left[627-\mathrm{C}_{18} \mathrm{H}_{31} \mathrm{CH}=\mathrm{C}=\mathrm{O}\right]^{+}\right)$, corresponding to loss of the arachidonyl as a ketene from $m / z 627$ is present in the product-ion spectrum of 18:0/20:4-PC. The analogous ions were also observed for 16:0/20:4-PC and 18:0/22:6-PC (data not shown), which possess a highly unsaturated fatty acyl at $s n-2$.

The $[\mathrm{M}+\mathrm{Li}-189]^{+}$ion at $m / z 627$ undergoes vigorous degradation after it is formed, as evidenced by its source CAD-MS ${ }^{2}$ spectrum (Figure $6 \mathrm{c}$ ), which contains abundant fragment ions including $\mathrm{m} / \mathrm{z}$ 341. The $[\mathrm{M}+$ Li-183 $]^{+}$ion at $m / z$ 633, however, appears to be stable and further dissociation is minimal (Figure 6d). The product-ion spectrum contains ions at $m / z 331$, corresponding to further loss of the $s n-2$ moiety as an $\alpha, \beta$-unsaturated fatty acid (loss of $\mathrm{C}_{17} \mathrm{H}_{27} \mathrm{CH}=\mathrm{CHCO}_{2} \mathrm{H}$ ), and the $m / z 309$ ion, corresponding to a $\left[\mathrm{C}_{17} \mathrm{H}_{27} \mathrm{CH}=\mathrm{CHCO}_{2} \mathrm{H}+\mathrm{Li}\right]^{+}$ion (Scheme 3a) $[11,14]$. This unique loss of fatty acid substituent as an $\alpha, \beta$-unsaturated fatty acid is also observed for the [M + Li-59- $\left.\mathrm{R}_{x} \mathrm{CO}_{2} \mathrm{H}\right]^{+}$precursor ions, which yield the $m / z 171$ ion (data not shown) (Scheme $3 \mathbf{b}$ ). In contrast, secondary degradation of the analogous ion at $m / z 577$ ([M +

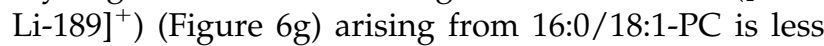
vigorous and results in mainly the acyl ions at $m / z 265$ $\left(\mathrm{R}_{2} \mathrm{CO}^{+}\right)$and $239\left(\mathrm{R}_{1} \mathrm{CO}^{+}\right)$, respectively (Scheme $3 \mathrm{c}$ ). The $m / z 583\left([\mathrm{M}+\mathrm{Li}-183]^{+}\right)$ion undergoes more vigorous degradations, as shown by its product-ion spectrum (Figure 6h). Therefore, the observation of abundance of $[\mathrm{M}+\mathrm{Li}-183]^{+}>\left[\mathrm{M}+\mathrm{Li}^{-189}\right]^{+}$for a diacyl-PC such as 18:0/20:4-PC which possesses a 

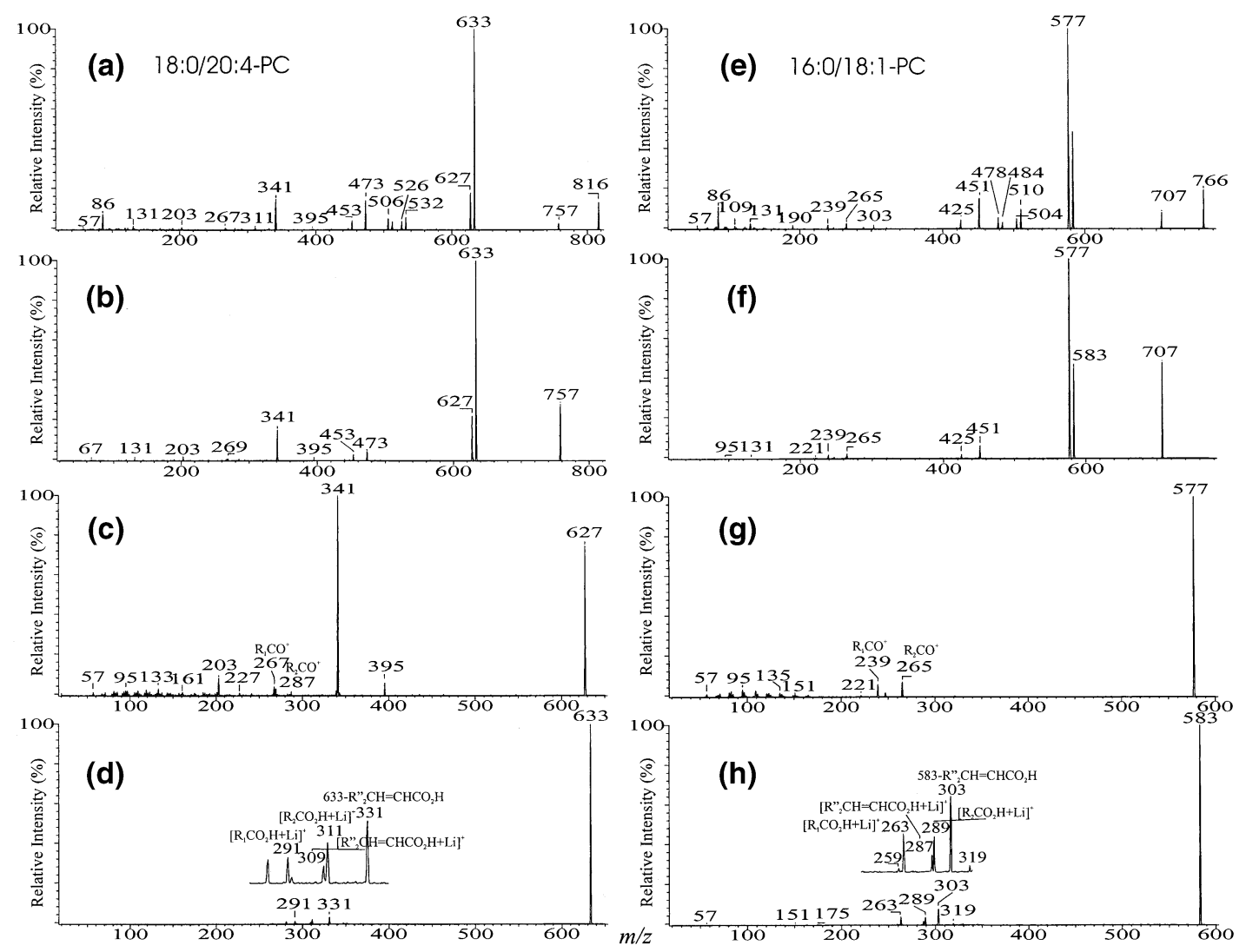

Figure 6. (a) The product-ion spectrum of the $[\mathrm{M}+\mathrm{Li}]^{+}$ion of 18:0/20:4-PC at $\mathrm{m} / \mathrm{z} 816.7$, and its source-CAD product-ion spectra of (b) $\mathrm{m} / \mathrm{z} 757$, (c) $\mathrm{m} / \mathrm{z}$ 627, and (d) $\mathrm{m} / \mathrm{z} 633$ ions; (e) The product-ion spectrum of $[\mathrm{M}+\mathrm{Li}]^{+}$ion of 16:0/18:1-PC at $\mathrm{m} / \mathrm{z}$ 766.6, and its source-CAD product-ion spectra arising from (f) $\mathrm{m} / \mathrm{z} 707$, (g) $\mathrm{m} / \mathrm{z}$ 577, and (h) $\mathrm{m} / \mathrm{z} 583$ ions.

highly unsaturated fatty acyl at $s n-2$, is attributable to the fact that the $[\mathrm{M}+\mathrm{Li}-183]^{+}$ion at $m / z 633$ is stable, but the $[\mathrm{M}+\mathrm{Li}-189]^{+}$ion at $m / z 627$ is labile and undergoes further dissociation to a major ion at $m / z 341$. This feature of the product-ion spectrum permits its distinction from a diacyl PC possessing fatty acyl substituents that are more saturated [6] and has been previously reported for diacyl phosphatidylethanolamine [14].

\section{Conclusions}

The major fragmentation processes leading to structural assignment of the fatty acid moieties and their location in the glycerol backbone for both the protonated and lithiated PC species involve the participation of the $\alpha$-hydrogen of the fatty acyl substituents. The $\alpha$-hydrogens of the fatty acyl at $s n-2$ are more labile than that at $s n-1$. This results in the abundances of $\left[\mathrm{M}+\mathrm{Li}-\mathrm{R}_{1} \mathrm{CO}_{2} \mathrm{H}\right]^{+}$greater than $[\mathrm{M}+\mathrm{Li}$ $\left.\mathrm{R}_{2} \mathrm{CO}_{2} \mathrm{H}\right]^{+}$and of $\left[\mathrm{M}+\mathrm{Li}-59-\mathrm{R}_{1} \mathrm{CO}_{2} \mathrm{H}\right]^{+}$greater than $\left[\mathrm{M}+\mathrm{Li}-59-\mathrm{R}_{2} \mathrm{CO}_{2} \mathrm{H}\right]^{+}$, for the $[\mathrm{M}+\mathrm{Li}]^{+}$species. The $\alpha$-hydrogens also participate in the formation of the $[\mathrm{M}+\mathrm{Li}-183]^{+}$and $[\mathrm{M}+\mathrm{Li}-189]^{+}$, via further dissociation of the $[\mathrm{M}+\mathrm{Li}-59]^{+}$ion. The fragmentation processes involving the $\alpha$-hydrogen are deterred by the substitution of the fatty acyl moieties with alkyl, alkenyl or hydroxyl groups. The substitution results in a distinct product-ion spectrum for each PC class, including diacyl-, plasmanyl-, plasmenyl-, and lyso-PC isomers. The preferential formation of the [M $\left.+\mathrm{H}-\mathrm{R}_{2} \mathrm{CH}=\mathrm{C}=\mathrm{O}\right]^{+}$ion over the $\left[\mathrm{M}+\mathrm{H}-\mathrm{R}_{1} \mathrm{CH}=\mathrm{C}=\mathrm{O}\right]^{+}$ ion for the $[\mathrm{M}+\mathrm{H}]^{+}$species is also attributable to the fact that the $\alpha$-hydrogens of the fatty acyl at $s n-2$ are more labile.

No preference in the formation of the $[\mathrm{M}+$ $\left.\mathrm{H}-\mathrm{R}_{x} \mathrm{CO}_{2} \mathrm{H}\right]^{+}$(where $x=1,2$ ) ions for the $[\mathrm{M}+\mathrm{H}]^{+}$ion of PCs was observed, indicating that the $\mathrm{R}_{x} \mathrm{CO}_{2} \mathrm{H}$ loss involving the participation of $\mathrm{H}^{+}$that protonates the molecule in gas phase is not regiospecific. The result is consistent with the findings that the impartial formation of the $\left[\mathrm{M}+\mathrm{Li}-\mathrm{R}_{x} \mathrm{CO}_{2} \mathrm{Li}\right]^{+}$(where $x=1,2$ ) ions by loss of $\mathrm{R}_{x} \mathrm{CO}_{2} \mathrm{Li}$ for the $[\mathrm{M}+\mathrm{Li}]^{+}$adduct ion involves the participation of the $\mathrm{Li}^{+}$ion that cationizes $\mathrm{PC}$ to $[\mathrm{M}+\mathrm{Li}]^{+}$.

\section{Acknowledgments}

This research was supported by United States Public Health Service grants P41-RR-00954, R37-DK-34388, P60-DK-20579, and P01-HL-57-278 and grant 996003 from the Juvenile Diabetes Foundation. 


\section{References}

1. Chapman, D.; Wallich, D. F. H. Biological Membranes; Academic: New York, 1989; p 71.

2. Op den Kamp, J. A. F. Lipid Asymmetry in Membranes. Annu. Rev. Biochem. 1979, 48, 47-71.

3. McMurray, W. C. Phospholipids in Subcellular Organelles and Membranes. In Form and Function of Phospholipids; Ansell, G. B.; Hawthorne, J. N. Dawson, R. M. C. Eds.; Elsevier Publishing: New York, 1973; p 205.

4. Ramanadham, S.; Borher, A.; Gross, R. W.; Turk, J. Mass Spectrometric Characterization of Arachidonate-Containing Plasmalogens in Human Pancreatic Islets and in Rat Islet $\beta$-Cells and Subcellular Membranes. Biochemistry 1993, 32, 13499-13509.

5. Murphy, R. C.; Harrison, K. A. FAB Mass Spectrometry of Phospholipids. Mass Spectrom. Rev. 1994, 13, 57-75.

6. Han, X.; Gross, R. W. Structural Determination of Picomole Amounts of Phospholipids via Electrospray Ionization Tandem Mass Spectrometry. J. Am. Soc. Mass Spectrom. 1995, 6, 1202-1210.

7. Hsu, F.-F.; Borher, A.; Turk, J. Formation of Lithiated Adducts of Glycerophosphocholine Lipids Facilitates Their Identification by Electrospray Ionization Tandem Mass Spectrometry. J. Am. Soc. Mass Spectrom. 1998, 9, 516-526.

8. Domingues, P.; Domingues, M. R. M.; Amado, F. M. L.; Ferrer-Correia, A. J. Characterization of Sodiated Glycerol
Phosphatidylcholine Phospholipids by Mass Spectrometry. Rapid Commun. Mass Spectrom. 2001, 15, 799-804.

9. Domingues, P.; Amado, F. M. L.; Marques, M. G. O. S.; Ferrer-Correia, A. J. Constant Neutral Loss Scanning for the Characterization of Glycerol Phosphatidylcholine Phospholipids. J. Am. Soc. Mass Spectrom. 1998, 9, 1189-1195.

10. Murphy, R. C.; Fiedler, J.; Hevko, J. Analysis of Nonvolatile Lipids by Mass Spectrometry. Chem. Rev. 2001, 101, 479526.

11. Hsu, F.-F.; Turk, J. Structural Characterization of Triacylglycerols as Lithiated Adducts by Electrospray Ionization Mass Spectrometry Using Low-Energy Collisionally Activated Dissociation on a Triple Stage Quadrupole Instrument. J. Am. Soc. Mass Spectrom. 1999, 10, 587-599.

12. Hsu, F.-F.; Turk, J.; Thukkani, A. K.; Messner, M. C.; Wildsmith, K. R.; Ford, D. A. Characterization of Alkylacyl, Alk-1Enylacyl, and Lyso Subclasses of Glycerophosphocholine by Tandem Quadrupole Mass Spectrometry with Electrospray Ionization, unpublished.

13. Han, X.; Gross, R. W. Structural Determination of Lysophospholipid Regioisomers by Electrospray Ionization Tandem Mass Spectrometry. J. Am. Chem. Soc. 1996, 118, 451-467.

14. Hsu, F.-F.; Turk, J. Characterization of Phosphatidylethanolamine as a Lithiated Adduct by Triple Quadrupole Tandem Mass Spectrometry with Electrospray Ionization. J. Mass Spectrom. 2000, 35, 595-606. 